\title{
Paratuberculosis control: a review with a focus on vaccination
}

\author{
Felix Bastida ${ }^{1}$ and Ramon A Juste $2^{2^{*}}$
}

\begin{abstract}
Mycobacterium avium subsp. paratuberculosis (MAP) infection causes in ruminants a regional chronic enteritis that is increasingly being recognized as a significant problem affecting animal health, farming and the food industry due to the high prevalence of the disease and to recent research data strengthening the link between the pathogen and human inflammatory bowel disease (IBD). Control of the infection through hygiene-management measures and test and culling of positive animals has to date not produced the expected results and thus a new focus on vaccination against this pathogen is necessary. This review summarizes all vaccination studies of cattle, sheep or goats reporting production, epidemiological or pathogenetic effects of vaccination published before January 2010 and that provide data amenable to statistical analyses. The meta analysis run on the selected data, allowed us to conclude that most studies included in this review reported that vaccination against MAP is a valuable tool in reducing microbial contamination risks of this pathogen and reducing or delaying production losses and pathogenetic effects but also that it did not fully prevent infection. However, the majority of MAP vaccines were very similar and rudimentary and thus there is room for improvement in vaccine types and formulations.
\end{abstract}

Keywords: Mycobacteria, paratuberculosis, cattle, sheep, goats, vaccine, protection, production effects, epidemiological effects, pathogenetic effects

\section{Introduction}

Paratuberculosis poses a big challenge to Veterinary Medicine and in particular to ruminant production. Since the first description of the disease in 1895 in a cow from Oldenburg, Friesland, its etiological agent, Mycobacterium avium subsp. paratuberculosis (MAP), has been shown to cause the disease in the majority of wild and domestic ruminant species $[1,2]$. This microbe is also present in many other hosts as well as the environment $[3,4]$. Even though the most important mycobacterial infection in animals, bovine tuberculosis, has been successfully controlled in nearly all developed countries, the other important mycobacterial infection, paratuberculosis, remains an unsolved problem for the veterinary scientific community still incapable of reaching a consensus on the better way to deal with it. This is so despite large control efforts in different countries during the past three decades.

\footnotetext{
* Correspondence: rjuste@neiker.net

${ }^{2}$ NEIKER-Tecnalia, Department of Animal Health, Berreaga 1, 48160 Derio, Bizkaia, Spain

Full list of author information is available at the end of the article
}

The mounting evidence showing that MAP is a factor in the pathogenesis of human inflammatory bowel disease (IBD) has increased the pressure to overcome this challenge. In spite of this, most of the undertakings are nevertheless based on the old principle that the only way to control an infectious disease is to eradicate its agent. This principle has worked well for some acute infections in times of survival struggle and profligate use of means but is increasingly difficult to apply because of demonstrated lack of efficacy and sustainability philosophy $[5,6]$. We are no longer faced with a live or death dilemma due to infectious diseases, but we have to deal with a need to increase productivity for the sake of improved and prolonged use of scarce resources. From this perspective, it is necessary to simultaneously exploit the three classical main approaches to eradicate or reduce the impact of paratuberculosis in herds or flocks. These are: 1) to introduce management changes to decrease the transmission of MAP, 2) to apply test and cull practices to eliminate the sources of infection, 3) to vaccinate replacers in order to increase their resistance to infection. The advantages and drawbacks of these strategies will be briefly examined.
C Biomed Central

(C) 2011 Bastida and Juste; licensee BioMed Central Ltd. This is an Open Access article distributed under the terms of the Creative Commons Attribution License (http://creativecommons.org/licenses/by/2.0), which permits unrestricted use, distribution, and reproduction in any medium, provided the original work is properly cited. 


\section{Management measures to decrease transmission of MAP} Management changes to reduce the transmission rate are widely accepted strategies that are compatible with all other approaches [7]. Furthermore, these changes have other positive side effects on farm productivity. Management measures focus mainly on avoiding contact between infected and susceptible young animals [8]. These measures include separating offspring from dams immediately after birth, feeding calves paratuberculosis-free colostrum supplement and milk replacement, raising replacement heifers in separate locations, avoiding manure fertilization of fields where replacement heifers grace, improving general farm hygiene, and eliminating practices that can bring infected foods or materials in contact with susceptible animals. In practice, it implies duplication of facilities and equipment, and meticulous working procedures. Also, another very important factor in the spread of paratuberculosis, which complicates the control of this disease through management measures, is the ability of MAP to survive in the environment for around one year $[9,10]$. Given the different settings and economic constraints of each individual farm, control measures may greatly vary form farm to farm. In addition, control measures should not be neglected when new animals are brought into a herd. Microbiological and serological results of all new animals, as well as, the paratuberculosis status and history of the herd of origin should always be taken into account before introducing new animals into the farm.

Although these measures might be viable for large dairy farms, the required changes may not be economical for many small dairy farms and are probably impossible to implement in beef cattle and sheep operations due to costs and disrupting effects. Moreover, these measures usually yield no immediate results and are easily abandoned when other productive constraints become more pressing [11]. In summary, this type of strategy has low engaging force and has little chance of being widely and successfully implemented in a whole region.

\section{Culling strategies to eliminate sources of infection}

Three variants of the testing and culling strategy prevail depending on the diagnostic method used to detect infected animals: fecal culture, ELISA or Polymerase Chain Reaction (PCR). The slow turn around rate or the low sensitivity of some of these test are the major problems in the efforts to control the disease [12].

\section{Fecal culture and culling}

It is generally accepted that this method detects infected animals first and is the most sensitive method [13,14]. Since it is based on identifying the agent when it is shed into the environment, culling these animals has a direct effect in preventing new infections. Fecal positive animals will also become clinical cases, and, therefore, the most visible effect of culling them is that clinical cases quickly disappear. The main problem with this approach is that the laboratory test is expensive, requires specialization, and its results are not available for several weeks or even months. As a result, progress in control of the disease is slow and often rather disappointing since positive animals keep on appearing over the years even after periods of negative results and absence of clinical cases. Its use for sheep and goats is prohibitively expensive unless it is carried out in pools. Another problem with this approach in farms heavily contaminated with MAP or in farms with super-shedders (animals that excrete 10,000 to 10 million MAP bacteria per gram of manure)[15] is the elimination of uninfected animals that give positive MAP results just because they are passing MAP bacteria through their gastrointestinal tract. This problem also affects PCR and culling strategy.

\section{ELISA and culling}

The ELISA test for paratuberculosis is generally considered to be highly specific, but of low sensitivity [14]. ELISA's simplicity, speed, low cost, and potential for automation makes it an ideal tool for laboratory diagnostic work [16]. The problems with ELISA test are that it has not yet been well studied how it will perform to control the disease and that the minimal sensitivity to reach eradication in a reasonable period of time is not guaranteed. In the best case scenario, inferring from the experience with fecal culture it can be assumed that ELISA testing and culling, if done often enough, will prevent the appearance of clinical cases, and slightly decrease the transmission risk. Additional problems with paratuberculosis ELISA are that sample handling appears to affect substantially the results of the test [17] and that the different commercially available diagnostic kits have very different efficacies [18,19], which therefore, can severely affect control programs. Given its costs are low and the results are obtained in less than a week, it is more easily accepted when positive results keep trailing along time since it is always possible to intensify control by testing more frequently. The regional ELISA specific strategies implemented up to now are rather complex and still not proven successful.

\section{PCR and culling}

The new type of strategy, albeit sparsely implemented, is the combination of PCR analysis of feces and culling of positive animals. In theory, this strategy should detect animals early in the infection process before antibodies are developed, and thus can quickly reduce the overall bacterial burden in the farm. However, the costs and the requirement of specialized personnel are major drawbacks of this technique. Until recently costs of PCR were extremely high for its use in animal health diagnostics. Dramatic reductions in reagent prices accompanied by improvements in 
technique sensitivity and especially in efficient highthroughput processing of samples and extraction of nucleic acids have made this approach a valuable strategy due to its high specificity, good sensitivity, and fast turnaround time $[20,21]$. The majority of paratuberculosis PCR detection tests are based on the detection of IS900 sequence, which has the benefit of multiple copies of target DNA per bacteria (higher sensitivity) but the disadvantage of a lower specificity since a few environmental mycobacteria also contain this insertion sequence. Other tests use MAP specific single copy genes (i.e. F57, 251) with theoretically lower sensitivity but higher specificity [22,23]. Multiplex PCRs, using combinations of target genes, have also been reported [24]. PCR has the additional benefit over the ELISA technique that, like fecal culture, it can provide quantitative bacterial content results, and thus high shedders and medium shedders can readily be identified and eliminated. Recently in the Netherlands, fecal culture has been replaced by a PCR based test in the Dutch paratuberculosis control program. As with the ELISA and culling strategy, PCR and culling is not yet proven in the field, however, a new study by Lu et al has shown that the use of faster detection tests such as PCR might be important in farms with poor management [25].

\section{Vaccination}

Vaccination, as a control measure for paratuberculosis, is probably the less accepted strategy although it is or has been used in all countries with substantial problems with this disease [26,27]. It is a highly cost-efficient strategy, which clearly prevents the appearance of clinical cases if done properly [27]. Vaccination strategies have been widely implemented for sheep in different countries with great success [27]. The main drawback to vaccination is that, since vaccines used in the field are not DIVA (differentiating infected from vaccinated), it can interfere with serological diagnosis of paratuberculosis and tuberculosis infections. Thus MAP vaccination might not allow eradication of the disease and it can interfere with national tuberculosis eradication programs. The latter is in fact the major hurdle affecting MAP vaccine approval for cattle by medical and agricultural authorities all over the world and the major deterrent for pharmaceutical companies to design new MAP vaccines for cattle. The most widely used tuberculosis diagnostic test in cattle is the single intradermal tuberculin test, and some cattle vaccinated with the currently available ovine or experimental MAP vaccines will become positive to this test. According to legislation in many countries, these animals are banned from international trade and should be slaughtered unless it can be proved that they are not infected with tuberculosis. New tuberculosis immunological diagnostic test, such as the gamma interferon release assay or the Enferplex ${ }^{\mathrm{TM}}$
TB assay, could help in the differentiation between MAP vaccinated and tuberculosis infected animals, but, improvements of these test might be required, since interference with tuberculosis diagnosis can still occasionally occur in MAP infected animals [28]. However, a modification of the single intradermal tuberculin test, the comparative intradermal tuberculin test, could solve the interference problem in the vast majority of cases. This test, which has been available for many years and is actually an official tuberculin test according to the OIE and EU legislation, consists of the simultaneous intradermal injection in two different sites of tuberculins from $\mathrm{Myco-}$ bacterium bovis (PPDbov) and Mycobacterium avium subsp. avium (PPDav). Higher reactivity to the avian tuberculin indicates infection or vaccination with avian type mycobacteria and allows to rule out mammal tuberculosis infection according to standardized criteria.

An additional drawback to MAP vaccination, which at least in sheep appears not to be of economical relevance [29], is the granulomatous lesion at the injection site produced by most oil-based bacterin vaccines.

In summary, there are several strategies for paratuberculosis control, but there is no generalized consensus on which one or which combination of strategies should be the standard approach. In our opinion, this is in part due to the fact that paratuberculosis control programs emphasize too heavily MAP eradication.

\section{Pathogenic background MAP distribution}

If we take a general view of our knowledge on paratuberculosis, we should point out that MAP is not a classical infectious agent fully complying with Koch's postulates. Indeed, we know that many experimental infections fail to establish the infectious agent in the intestinal tissue and to cause the disease [30-33]. We also know that frequently the initial focal lesions do not progress to clinical stages. More recent evidence has revealed that it is not rare for herds with no clinical history of paratuberculosis and even with a history of negative fecal culture to occasionally show positive fecal culture results [34]. In addition, recent studies on paratuberculosis prevalence have revealed that as many as $60 \%$ of some national herds are actually infected [35]. Finally, Pickup and collaborators have shown that MAP is present in the environment at a previously unsuspected high frequency [4]. All this evidence indicates that MAP might be a necessary, but not a sufficient cause of paratuberculosis. Under these conditions, we should therefore ask ourselves: Is paratuberculosis eradication a realistic goal? Is it necessary? Is it profitable for the society in general? Answers to these questions are not readily available because we lack accurate information on the actual distribution of MAP and its potential impact on 
human health. Reviewing aspects of the pathogenesis and epidemiology may lay the grounds on which control alternative(s) to choose.

\section{Forms of infection}

Multiple forms of infection can be observed in MAP infected animals. The form present in an animal will not only depend on the progression of the infection or stage of the disease, but also on many other factors including an individual's genetic resistance or susceptibility to the pathogen, age at the time of infection, and previous exposure to other environmental mycobacteria. On Figure 1, we illustrate the balance between the infection and the animal's immune system and their corresponding forms of infection. According to different studies, about $46 \%$ of cattle, $51 \%$ of sheep, and $50 \%$ of goats in a MAP-contaminated environment do not show any signs of infection [36-38]. Since these animals live in a heavily contaminated environment, they must continuously be exposed to MAP, and, therefore, they either prevent the infection or very quickly clear up the establishment of local infection foci.
Because it is not rare for such animals to carry MAP and plenty of experimental evidence has shown that administration of large amounts of MAP not always results in the development of a full blown infection, quite the opposite frequently produces very regressive lesions, the more likely explanation is that there is a balance between MAP and the host that in about half of the exposed individuals results in containing the infection (Figure 1). Beyond this balance point there are also different stages of infection. About $19 \%$ of cattle, $24 \%$ of sheep and $12 \%$ of goats carry an infection which is very focal and delimited. Around $17 \%$ and $9 \%$ of cattle and sheep, respectively, have multifocal forms. Of the animals presenting diffuse forms, approximately $19 \%$ of cattle, $16 \%$ of sheep and $38 \%$ of goats develop into diffuse forms which lead to animals showing clinical signs and to their death.

\section{Vaccine types}

Both live (non-attenuated and attenuated) and killed whole cell vaccines have been used against paratuberculosis. In a few cases, subunit vaccines consisting of sonicated

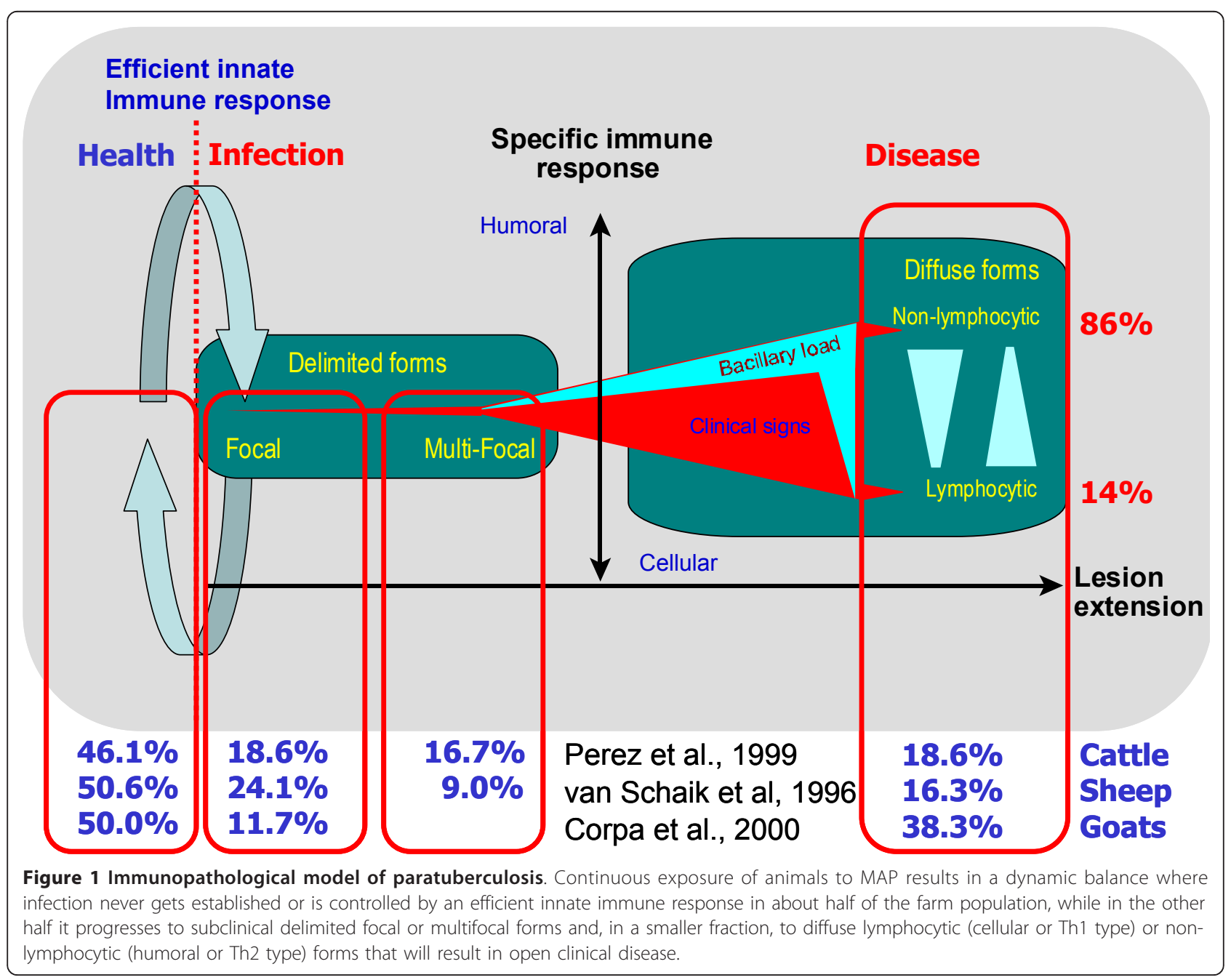


bacteria, bacterial cell fractions or recombinant MAP antigens have been used but they have shown a much lower degree of protection $[39,40]$. More recently, DNA vaccines, consisting of the inoculation of mammalian expression vectors containing MAP genes have also been used in mice, humans and sheep but not in cattle [41-47]. Most MAP vaccine formulations have been based on mycobacteria and a water-in-oil emulsion (olive, mineral, liquid, paraffin, etc). Some have also an irritant like pumice powder in order to increase and stimulate the local inflammatory response, and therefore enhance the immunogenicity of the vaccine. The goal of these vaccines is to establish a focus of inflammation where the antigens can permanently stimulate the host immune system. Under this principle, it would not be necessary to revaccinate animals because the slow liberation of antigens from the vaccination site keeps on stimulating the immune system, at least during the period before the age of initial clinical disease presentation.

\section{Vaccination age}

Paratuberculosis vaccines are recommended for exclusive use in very young animals on the grounds that this is necessary to prevent infection and to decrease interfering responses with the diagnosis of tuberculosis. Actually, the experience on animals older than 1 month is rather scarce, however recent studies on the pathogenesis as well as some field data suggest that vaccination of adult or subadult animals might have some management (no need for separate handling, vaccination of only replacers) and therapeutic (stronger humoral and cellular responses) advantages that need to be taken into account $[48,49]$. More recent evidence form Australian sheep vaccination trials indicate that there might be an age threshold for vaccine efficacy that can be drawn at around 8 months of age [50].

\section{Reassessment of vaccination results Literature on vaccination}

There is an increasing number of vaccination studies in ruminant species focused on different aspects of the use of MAP vaccines including two recent reviews on the topic $[51,52]$. The most recent review by Rosseels et al. focused mainly on the immunological aspects of MAP vaccination [52]. For the purpose of the present review we have used only vaccinations studies of cattle, sheep or goats reporting production, epidemiological or pathogenetic effects and data that could be used to estimate the reduction rates of damage or contamination. Production effects relate to the losses measured as the frequency of clinical cases or mortality rates. We considered epidemiological effects as the microbiological contamination risks measured by the frequency or amount of MAP isolations in fecal or tissue cultures. And finally, pathogenetic effects pertain to the modification in the course of the disease as measured by the frequency of specific histopathological lesions.
Searches of published material before January 2010 were run using three strategies: First, specific searches of combinations of the words vaccination, vaccine and paratuberculosis were run on Current Contents or Pubmed and the hits were screened for articles meeting the conditions stated above. Second, the same combinations of words were used in Google (http://www.google.com) to obtain studies from doctoral dissertations and other sources. Third, literature data on vaccination trials collected over a period of 25 years at NEIKER was also examined systematically. More than half the published studies included in this meta-analysis describe field reports, which actually might give a better view of the whole problem of vaccination, since highly controlled experimental trials might be misleading because of the lack of interferences from field conditions.

The very first report on paratuberculosis vaccination of cattle is that by Vallée and Rinjard in 1926 [53]. It is not until 1960 that a similar vaccine was reported to have been used in sheep [54]. As for goats, although it is known that vaccines have been used in Spain in the 70 's, the first written report on its efficacy dates back to 1985 in Norway [26].

\section{Paratuberculosis vaccination meta-analysis}

Taking worldwide published reports on paratuberculosis vaccination available to us but not restricted to peerreviewed papers, we have classified the studies according to species (cattle, sheep or goats), and type of evaluation of vaccine efficacy (production, epidemiological or pathogenetic effects). We have kept only those studies were the authors reported either vaccinated versus control group or pre-vaccination versus post-vaccination cohorts in numerical terms. In all, except in one study where a scoring system was used for MAP isolation, results were presented as the frequency of positive/affected individuals over total animals in the study. We have not been overly critical on the criteria applied by authors, but instead we have assumed that they knew well the disease and that their study design was sound.

All data have been transformed into a reduction percent calculated as the frequencies difference divided by the frequency in the control group. For each category of species and type of evaluation, we have calculated a size-weighted reduction average for the whole set of studies in that category. The same size-weighting method has been previously used to calculate a standard deviation in order to define the $95 \%$ confidence limits of the estimate [55].

\section{Results}

A total of 118 experiments from 63 reports and 14 countries have been used for the meta-analysis in this review (Tables 1 and 2). The USA was the country with the highest number of studies included (26.3\%), followed by New Zealand (14.4\%) and then closely by Spain (13.6\%). 
Table 1 Countries where the vaccination experiments* used in the meta-analysis were carried out

\begin{tabular}{lcc}
\hline Country & Number of Experiments & Percent \\
\hline Australia & 12 & 10.2 \\
Denmark & 1 & 0.8 \\
France & 5 & 4.2 \\
Germany & 1 & 0.8 \\
Greece & 6 & 5.1 \\
Hungary & 1 & 0.8 \\
Iceland & 2 & 1.7 \\
India & 4 & 3.4 \\
Netherlands & 12 & 10.2 \\
New Zealand & 17 & 14.4 \\
Norway & 1 & 0.8 \\
Spain & 16 & 13.6 \\
United Kingdom & 9 & 7.6 \\
United States & 31 & 26.3 \\
Total & 118 & \\
\hline
\end{tabular}

* An experiment is defined as vaccine trial whose results are measured according to one of the three outcome variables: clinical signs, MAP isolation, gross or microscopic lesions.

Some countries, such as the USA, have studies throughout the years, however, interest in MAP vaccination studies change among countries. For example, early large studies in the UK and France, gave way to studies in The Netherlands, New Zealand, Australia and Spain. This pattern might reflect MAP prevalence levels and research funding priorities in the different countries, but most likely it is also biased by administrative regulations limiting the availability of a successful commercial vaccine for sheep and goats (Gudair ${ }^{\mathrm{TM}}$ ), which is being widely used in countries with large sheep populations. 45 experiments were conducted in cattle, 49 in sheep, and 24 in goats (Table 2). Apart from the studies where small ruminants were used either because they were the target species of the commercial vaccine or because they are an easier to handle and a less costly animal model, there is a relation between the type of animal used in the study and the main livestock in the country.

Half of the studies are field trials where animals were naturally exposed to MAP. In these studies, results were assessed either by comparison between initial prevalence before vaccination, and final prevalence some time postvaccination, or by following up a matched group within

Table 2 Experiments and reports used for the metaanalysis

\begin{tabular}{lcc}
\hline Species & Experiments & Reports* $^{*}$ \\
\hline Cattle & 45 & 33 \\
Sheep & 49 & 21 \\
Goats & 24 & 9 \\
\hline
\end{tabular}

* A report is a publication or communication that might contain results of one or more experiments. the same herd or flock. The later type of studies, when the control group is housed with vaccinated animals, frequently underestimates the positive effects of vaccination, because as herd immunity increases, bacterial shedding into the environment is reduced and thus the probability of a natural infection in the control group is also reduced. In three experiments the assessment was done using control unvaccinated herds, and one consisted of a questionnaire on clinical incidence in farms before and after using vaccination.

Tables 3,4 and 5 summarize the results of all vaccination experiments used for the meta-analysis. Less than a third of them are not standard peer review journal publications (Doctoral Dissertations, non-peer review magazines, conference proceedings, bulletin reports, memoranda, or other types of documents). Some appear to be advances of results that have been published later. Since the information is different, we have treated them as individual experiments, although we were aware that they might introduce a bias to underestimate vaccination positive effects, particularly regarding culture results because of their lack of time span for the vaccine to make its mid- to long-term effects.

The vast majority of studies on all species showed positive reductions in all examined variables (Figure 2), that in cattle resulted in average reductions of $96.0 \%, 72.6 \%$ and $57.5 \%$ for production, epidemiological or pathogenetic effects, respectively. In sheep these reductions were of $67.5 \%, 76.4 \%$ and $89.7 \%$ and in goats of $45.1 \%, 79.3 \%$ and $94.8 \%$, clearly demonstrating that MAP vaccination works well in all three species. The widest spread in reduction percentages, including several negative reduction rates, was observed with the epidemiological effects variable, which represents culture data. These differences are probably due to inherent aspects of each variable, since frequently the same study that gave negative reduction rates with the epidemiological variable, showed much better reduction results with the other variables, specially for the production effects variable. Most studies reported culture data as positive or negative result and did not include data on quantification of bacterial load in the sample. Thus, vaccinated animals with clinical signs reduction were still infected and excreted bacteria. This would imply that even though the amount of bacterial shedding might have been reduced, the proportion of shedding animals might have not. As a consequence, this would be in agreement with the widely accepted concept that, in general, current MAP vaccines can contain the infection and dramatically decrease clinical signs in a herd, but do not completely clear the infection.

Except for a few cases, vaccination in cattle was applied at early ages, in the first weeks of life, while in sheep more studies included adult sheep. The largest sample size studies, up to 150,000 animals, were done in cattle and preferentially recorded production effects in terms of 
Table 3 Production effects (Paratuberculosis clinical cases or mortality rates).

\section{Vaccine \\ Country and reference}

Year Number of animals

Age at vaccination

Reduction

Type of trial

(\%)

\begin{tabular}{|c|c|c|c|c|c|c|c|c|c|}
\hline Name/Laboratory & Type & Strain/Antigen & Adjuvant & & & & & & \\
\hline \multicolumn{10}{|c|}{ Cattle } \\
\hline NCV & Live & 6 strains & Oil & U.S.A. [65] & 1935 & 20 & $1 \mathrm{~m}$ & 100,00 & $E, M C, C C$ \\
\hline Weybridge & Live & $316 F$ & $\mathrm{P} / \mathrm{O} / \mathrm{P}$ & U.K. [66] & 1959 & 63401 & $1 \mathrm{~m}$ & 93.45 & $F, I F, C C$ \\
\hline Weybridge & Live & $316 \mathrm{~F}$ & $\mathrm{P} / \mathrm{O} / \mathrm{P}$ & U.K. [67] & 1964 & 2440 & $1 \mathrm{~m}$ & 98.36 & $F, I F, C C$ \\
\hline Weybridge & Live & $316 \mathrm{~F}$ & $\mathrm{P} / \mathrm{O} / \mathrm{P}$ & U.K. [68] & 1965 & 84 & $1 w$ & 46.67 & $E, M C, C C$ \\
\hline Weybridge & Live & $316 \mathrm{~F}$ & $\mathrm{P} / \mathrm{O} / \mathrm{P}$ & U.K. [69] & 1982 & 150000 & $1 \mathrm{~m}$ & 99.06 & $F, I F, C C$ \\
\hline Fromm & Killed & M.a.a strain 18 & Oil & U.S.A. [70] & 1983 & 48 & $1 \mathrm{~m}$ & 35.29 & $F, M C, C C$ \\
\hline- & Live & $316 \mathrm{~F}$ & $\mathrm{P} / \mathrm{O} / \mathrm{P}$ & France [61] & 1988 & 902 & $1 \mathrm{~m}$ & 87.34 & $F, I F, C C$ \\
\hline- & Live & $316 \mathrm{~F}$ & $\mathrm{P} / \mathrm{O} / \mathrm{P}$ & France [61] & 1988 & 1037 & $1 \mathrm{~m}$ & 97.22 & $F, I F, C C$ \\
\hline Lelystad & Killed & - & Oil & Netherlands [59] & 1988 & 851 & $1-24 m$ & 87.05 & $F, I F, C C$ \\
\hline Lelystad & Killed & - & Oil & Netherlands [71] & 1992 & 61050 & $1 \mathrm{~m}$ & 91.82 & $F, M C, C C$ \\
\hline NCV & Killed & - & Oil & Netherlands [72] & 1994 & 337 & $1 \mathrm{~m}$ & 79.01 & $F, I F, C C$ \\
\hline NCV & Killed & - & Oil & Netherlands [37] & 1996 & 573 & $1 \mathrm{~m}$ & 68.14 & F, CC \\
\hline \multicolumn{8}{|c|}{ Average } & \multicolumn{2}{|c|}{$96.02 \pm 0.01$} \\
\hline \multicolumn{10}{|c|}{ Sheep } \\
\hline $\mathrm{NCV}$ & Live & $316 \mathrm{~F}$ & Oil Paraffin & Greece [73] & 1988 & 1448 & $1 \mathrm{~m}$ & 76.14 & $\mathrm{~F}, \mathrm{MC}, \mathrm{TM}$ \\
\hline NCV & Live & $316 \mathrm{~F}$ & Oil Paraffin & Greece [73] & 1988 & 5526 & Adults & 28.74 & $\mathrm{~F}, \mathrm{MC}, \mathrm{TM}$ \\
\hline Lio-Johne & Live & $316 \mathrm{~F}$ & Oil & Spain [74] & 1993 & 1201 & Adults & 78.29 & $F, M C, C C$ \\
\hline Lio-Johne & Live & $316 \mathrm{~F}$ & Oil & Spain [75] & 1995 & 570 & $1 \mathrm{~m}$ & 52.55 & $F, M C, T M$ \\
\hline Weybridge & Live & $316 \mathrm{~F}$ & $\mathrm{P} / \mathrm{O} / \mathrm{P}$ & U.K. [76] & 1993 & 830 & Adults & 89.86 & $F, I F, C C$ \\
\hline Neoparasec \& NCV & Live \& Killed & $\begin{array}{c}316 \mathrm{~F} \\
-\end{array}$ & $\begin{array}{l}\text { Oil } \\
\text { Oil }\end{array}$ & Spain [77] & 1995 & 857 & Adults & 54.55 & $F, I F, C C$ \\
\hline Neoparasec & Live & $316 \mathrm{~F}$ & Oil & New Zealand [78] & 2000 & 28 & 1-1.5 m & 71.43 & $E, M C, C C$ \\
\hline Gudair & Killed & $316 \mathrm{~F}$ & Oil & Australia [79] & 2003 & 8000 & $3,8 \mathrm{~m}, 2 \mathrm{y}$ & 87.50 & $F, I F$, mort rate \\
\hline Gudair & Killed & $316 \mathrm{~F}$ & Oil & Australia [80] & 2004 & 1200 & $1-4 \mathrm{~m}$ & 90.00 & $\mathrm{~F}, \mathrm{MC}$, mort reduction \\
\hline Gudair & Killed & $316 \mathrm{~F}$ & Oil & Australia [34] & 2006 & 400 & $1-3 \mathrm{~m}$ & 91.25 & $F, M C, T M$ \\
\hline Gudair & Killed & $316 \mathrm{~F}$ & Oil & New Zealand [81] & 2009 & 65 & $4 \mathrm{~m}$ & 78.57 & $E, M C, C A$ \\
\hline NCV & Killed & $316 \mathrm{~F}$ & Lipid-K formulation & New Zealand [81] & 2009 & 65 & $4 \mathrm{~m}$ & 57.14 & $E, M C, C A$ \\
\hline NCV & Live & $316 \mathrm{~F}$ & Lipid-K formulation & New Zealand [81] & 2009 & 65 & $4 \mathrm{~m}$ & 14.29 & $E, M C, C A$ \\
\hline NCV & Live & $316 \mathrm{~F}$ & Lipid-K formulation & New Zealand [81] & 2009 & 65 & $4 \mathrm{~m}$ & 35.71 & $E, M C, C A$ \\
\hline \multicolumn{8}{|c|}{ Average } & \multicolumn{2}{|c|}{$67.57 \% \pm 0.35$} \\
\hline \multicolumn{10}{|c|}{ Goats } \\
\hline $\mathrm{NCV}$ & Live & $316 \mathrm{~F}$ & Oil Paraffin & Greece [73] & 1988 & 2178 & $1 \mathrm{~m}$ & 82.78 & $\mathrm{~F}, \mathrm{MC}, \mathrm{TM}$ \\
\hline $\mathrm{NCV}$ & Live & $316 \mathrm{~F}$ & Oil Paraffin & Greece [73] & 1988 & 7773 & Adults & 34.52 & $F, M C, T M$ \\
\hline
\end{tabular}

NCV: non-commercial vaccine; Weybridge: Central Veterinary Laboratory, Weybridge, UK; Fromm: Fromm Laboratories, Grafton, Wisconsin USA; Lelystad: Central Veterinary Institute, Lelystad, The Netherlands; LioJohne, Ovejero, Spain; Neoparasec: Neoparasec ${ }^{\mathbb{\circledR}}$, Merial; Gudair: Gudair ${ }^{\circledR}$, CZ Veterinaria/Pfizer; P/O/P Paraffin, Olive Oil, Pumice Stone Powder; y: year(s); m: month(s); w: week(s); d: day(s); F: Field trial; E: Experimental infection; MC: Comparison to matched controls; IF: Comparison of initial versus final prevalence; TM: Total mortality; CC: clinical cases; NVH: Comparison to non-vaccinating herds. 
Table 4 Epidemiological effects (Mycobacterium avium subsp. paratuberculosis isolation from faeces or tissues).

\begin{tabular}{|c|c|c|c|c|c|c|c|c|c|}
\hline \multicolumn{4}{|c|}{ Vaccine } & \multirow[t]{2}{*}{ Country and reference } & \multirow[t]{2}{*}{ Year } & \multirow[t]{2}{*}{ Number of animals } & \multirow[t]{2}{*}{ Age at vaccination } & \multirow[t]{2}{*}{ Reduction (\%) } & \multirow[t]{2}{*}{ Type of trial } \\
\hline Name/Laboratory & Type & Strain/Antigen & Adjuvant & & & & & & \\
\hline \multicolumn{10}{|c|}{ Cattle } \\
\hline NCV & Live & 6 strains & Oil & U.S.A. [65] & 1935 & 20 & $1 \mathrm{~m}$ & -14.29 & $\mathrm{E}, \mathrm{TC}$ \\
\hline Weybridge & Live & $316 \mathrm{~F}$ & $\mathrm{P} / \mathrm{O} / \mathrm{P}$ & U.K. [68] & 1965 & 84 & $1 \mathrm{w}$ & 11.54 & $\mathrm{E}, \mathrm{MC}, \mathrm{TC}$ \\
\hline Weybridge & Live & $316 \mathrm{~F}$ & $\mathrm{P} / \mathrm{O} / \mathrm{P}$ & Australia [82] & 1971 & 82 & $1 \mathrm{~m}$ & 24.18 & $F, I F, M C, T C$ \\
\hline NCV & Live & avirulent & $\mathrm{P} / \mathrm{O} / \mathrm{P}$ & U.S.A. [83] & 1974 & 16 & $16 d$ & 81.47 & $E, M C, F C$ \\
\hline NCV & Live & avirulent & $\mathrm{P} / \mathrm{O} / \mathrm{P}$ & U.S.A. [83] & 1974 & 16 & $16 d$ & 0.00 & E, MC, TC \\
\hline Fromm & Killed & M.a.a strain 18 & Oil & U.S.A.[70] & 1983 & 158 & $1 \mathrm{~m}$ & 79.28 & $F, M C, F C$ \\
\hline Fromm & Killed & M.a.a strain 18 & Oil & U.S.A. [70] & 1983 & 3060 & $1 \mathrm{~m}$ & 99.11 & $F, I F, F C$ \\
\hline NCV & Live & $316 \mathrm{~F}$ & Oil & Denmark [84] & 1983 & 5446 & $1 \mathrm{~m}$ & 92.90 & $F, M C, F C$ \\
\hline Lelystad & Killed & - & Oil & Netherlands [71] & 1992 & 2065 & $1 \mathrm{~m}$ & -21.25 & $F, I F, F C$ \\
\hline NCV & Live & $316 \mathrm{~F}$ & $\mathrm{P} / \mathrm{O} / \mathrm{P}$ & France [85] & 1992 & 22988 & $1 \mathrm{~m}$ & 81.68 & $F, I F / M C, F C$ \\
\hline Phylaxia & Killed & 5889 Bergey & Oil & Hungary [86] & 1994 & 2738 & $1 \mathrm{~m}$ & 94.70 & $F, I F, F C$ \\
\hline NCV & Killed & - & Oil & Netherlands [72] & 1994 & 499 & $1 \mathrm{~m}$ & -36.72 & $F, I F, T C$ \\
\hline NCV & Killed & - & Oil & Netherlands [37] & 1996 & 573 & $1 \mathrm{~m}$ & 13.34 & $F, I F, T C$ \\
\hline Mycopar & Killed & M.a.a strain 18 & Oil & U.S.A.[87] & 2000 & 372 & $<35 d$ & 71.43 & $F, M C, F C$ \\
\hline NCV & Killed & - & Oil & Netherlands [88] & 2001 & 4452 & $1 \mathrm{~m}$ & 33.83 & $F, N V H, F C$ \\
\hline Neoparasec & Live & $316 \mathrm{~F}$ & Oil & Germany [89] & 2002 & 521 & $1 \mathrm{~m}$ & 86.87 & $F, M C, F C$ \\
\hline Mycopar & Killed & M.a.a strain 18 & Oil & U.S.A. [58] & 2003 & 10 & $7 d$ & -28.00 & $E, M C, F C, T C$ \\
\hline $\begin{array}{l}\text { Mycopar } \\
\text { IL-12 }\end{array}$ & Killed & M.a.a strain 18 & Oil & U.S.A. [58] & 2003 & 10 & $7 d$ & 32.00 & E, MC, FC, TC \\
\hline Mycopar & Killed & M.a.a strain 18 & Oil & U.S.A. [58] & 2003 & 14 & $8 d$ & 40.00 & E, MC, FC, TC \\
\hline $\begin{array}{l}\text { Mycopar } \\
\text { IL-12 }\end{array}$ & Killed & M.a.a strain 18 & Oil & U.S.A. [58] & 2003 & 14 & $8 d$ & 23.60 & E, MC, FC, TC \\
\hline Silirum & Killed & $316 \mathrm{~F}$ & Oil & Spain [90] & 2005 & 14 & $2 \mathrm{~m}$ & 62.50 & $\mathrm{E}, \mathrm{MC}, \mathrm{TC}$ \\
\hline NCV & Rec & Hsp70 & DDA & Netherlands [39] & 2006 & 20 & $\begin{array}{c}1 \mathrm{~m} \\
\text { boost } 11 \mathrm{~m}\end{array}$ & 37.50 & $E, M C, F C$ \\
\hline Mycopar & Killed & M.a.a strain 18 & Oil & U.S.A. [91] & 2006 & 213 & $<35 d$ & 77.12 & $F, M C, F C$ \\
\hline NCV & $\operatorname{Rec}$ & MAP $(85 \mathrm{~A}, 85 \mathrm{~B}, 85 \mathrm{C}, \mathrm{SOD})$ & MPLA +/- IL12 RIBI & U.S.A. [92] & 2008 & 24 & $5-10 d$ & 41.67 & E, MC, FC, TC \\
\hline Silirum & Killed & $316 \mathrm{~F}$ & Oil & U.S.A. [93] & 2009 & 12 & $14 d$ & 84.61 & E,MC,TC \\
\hline Silirum & Killed & $316 \mathrm{~F}$ & Oil & Spain [49] & 2009 & 371 & all ages & 68.20 & $F, I F, F C, F P$ \\
\hline \multicolumn{8}{|c|}{ Average } & \multicolumn{2}{|c|}{$72.55 \pm 0.29$} \\
\hline \multicolumn{10}{|c|}{ Sheep } \\
\hline $\mathrm{NCV}$ & Killed & 101 sheep \& VB/4 cattle & Oil & U.K. [94] & 1961 & 44 & $1 \mathrm{~m}$ & 52.63 & $\mathrm{E}, \mathrm{MC}, \mathrm{TC}$ \\
\hline NCV & Killed & - & Oil & U.K. [95] & 1962 & 126 & $1 \mathrm{~m}$ & 29.05 & E, MC, TC \\
\hline Lio-Johne & Live & $316 F$ & Oil & Spain [74] & 1993 & 1201 & Adults & 80.01 & $\mathrm{~F}, \mathrm{MC}, \mathrm{TC}$ \\
\hline Neoparasec & Live & $316 \mathrm{~F}$ & Oil & Spain [96] & 1994 & 13 & $2 \mathrm{~m}$ & 38.89 & E, MC, TC \\
\hline
\end{tabular}


Table 4 Epidemiological effects (Mycobacterium avium subsp. paratuberculosis isolation from faeces or tissues). (Continued)

\begin{tabular}{|c|c|c|c|c|c|c|c|c|c|}
\hline Neoparasec \& NCV & Live \& Killed & $\begin{array}{c}316 \mathrm{~F} \\
-\end{array}$ & Oil & Spain [77] & 1995 & 97 & Adults & -10.95 & $F, I F, T C$ \\
\hline NCV & Killed & - & Oil Paraffin & Greece [97] & 1997 & 226 & $1 \mathrm{~m}$ & 93.27 & $F, M C, F C$ \\
\hline Neoparasec & Live & $316 \mathrm{~F}$ & Oil & New Zealand [78] & 2000 & 28 & $1-1.5 \mathrm{~m}$ & 66.67 & $\mathrm{E}, \mathrm{MC}, \mathrm{TP}$ \\
\hline Gudair & Killed & $316 \mathrm{~F}$ & Oil & Australia [80] & 2004 & 1200 & $1-4 \mathrm{~m}$ & 90.00 & $F, M C, F C$ \\
\hline Gudair & Killed & $316 \mathrm{~F}$ & Oil & Australia [98] & 2005 & - & $16 w$ & 52.21 & $F, I F, F C$ \\
\hline Gudair & Killed & $316 \mathrm{~F}$ & Oil & Australia [34] & 2006 & 400 & $1 \mathrm{~m}$ & 76.14 & $F, M C, F C$ \\
\hline Gudair & Killed & $316 \mathrm{~F}$ & Oil & Australia [34] & 2006 & 400 & $1 \mathrm{~m}$ & 84.15 & $F, M C, F C$ \\
\hline Gudair & Killed & $316 \mathrm{~F}$ & Oil & Australia [99] & 2007 & 998 & $2-3 m$ & 76.14 & $F, M C, F C$ \\
\hline Gudair & Killed & $316 \mathrm{~F}$ & Oil & New Zealand [81] & 2009 & 62 & $4 \mathrm{~m}$ & 25.30 & $E, M C, F C$ \\
\hline NCV & Killed & $316 \mathrm{~F}$ & Lipid-K formulation & New Zealand [81] & 2009 & 63 & $4 \mathrm{~m}$ & 36.03 & $E, M C, F C$ \\
\hline NCV & Live & $316 \mathrm{~F}$ & Lipid-K formulation & New Zealand [81] & 2009 & 63 & $4 \mathrm{~m}$ & 36.03 & $E, M C, F C$ \\
\hline $\mathrm{NCV}$ & Live & $316 \mathrm{~F}$ & Lipid-K formulation & New Zealand [81] & 2009 & 62 & $4 \mathrm{~m}$ & 34.09 & $E, M C, F C$ \\
\hline \multicolumn{8}{|c|}{ Average } & \multicolumn{2}{|c|}{$76.42 \pm 0.54$} \\
\hline \multicolumn{10}{|c|}{ Goats } \\
\hline Neoparasec & Live & $316 \mathrm{~F}$ & Oil & France [100] & 1988 & 27 & $1 \mathrm{~m}$ & 73.08 & $E, M C, F C$ \\
\hline Neoparasec & Live & $316 \mathrm{~F}$ & Oil & France [100] & 1988 & 26 & $1 \mathrm{~m}$ & 51.01 & E, MC, TC \\
\hline Fromm & Killed & - & Freund's Complete & U.S.A. [101] & 1988 & 1075 & $1 \mathrm{~m}$ & 80.23 & $F, M C, F C$ \\
\hline NCV & Killed & - & Oil Paraffin & Greece [97] & 1997 & 297 & $1 \mathrm{~m}$ & 95.57 & $\mathrm{~F}, \mathrm{NVH}, \mathrm{FC}$ \\
\hline NCV & Killed & Goat isolate (CWD) & QS21 & U.S.A. [102] & 2007 & 20 & $1-4 w$ & 61.69 & $\mathrm{E}, \mathrm{MC}, \mathrm{FC}, \mathrm{TC}$ \\
\hline NCV & Killed & Goat isolate (CWC) & QS21 & U.S.A. [102] & 2007 & 20 & $1-4 w$ & 85.19 & $\mathrm{E}, \mathrm{MC}, \mathrm{FC}, \mathrm{TC}$ \\
\hline NCV & Killed & Goat isolate (CWC) & Alum & U.S.A. [102] & 2007 & 20 & $1-4 w$ & 79.31 & $\mathrm{E}, \mathrm{MC}, \mathrm{FC}, \mathrm{TC}$ \\
\hline NCV & Killed & Goat isolate (CWD) & Alum & U.S.A. [102] & 2007 & 20 & $1-4 w$ & -57.68 & $E, M C, F C, T C$ \\
\hline NCV & Killed & Virulent Field Strain & Alum & India [48] & 2007 & 55 & $4-6 m$ & 82.14 & $E, M C, F C$ \\
\hline Gudair & Killed & $316 \mathrm{~F}$ & Oil & India [48] & 2007 & 55 & $4-6 m$ & 52.38 & $E, M C, F C$ \\
\hline NCV & $\operatorname{Rec}$ & MAP $(85 \mathrm{~A}, 85 \mathrm{~B}, \mathrm{SOD}, 74 \mathrm{~F})$ & DDA & U.S.A. [40] & 2009 & 17 & $5-10 d$ & 87.50 & $\mathrm{E}, \mathrm{MC}, \mathrm{TC}$ \\
\hline $\mathrm{NCV}$ & $\operatorname{Rec}$ & MAP $(85 \mathrm{~A}, 85 \mathrm{~B}, 50 \mathrm{D}, 74 \mathrm{~F})$ & none & U.S.A. [40] & 2009 & 17 & $5-10 d$ & 37.50 & $\mathrm{E}, \mathrm{MC}, \mathrm{TC}$ \\
\hline
\end{tabular}

NCV: non-commercial vaccine; Weybridge: Central Veterinary Laboratory, Weybridge, UK; Fromm: Fromm Laboratories, Grafton, Wisconsin USA; Lelystad: Central Veterinary Institute, Lelystad, The Netherlands; Phylaxia: Phylaxia Veterinary Biologicals Company, Budapest; Mycopar ${ }^{\mathbb{R}}$ : Mycopar Fort Doge/Solvay, USA; Neoparasec: Neoparasec ${ }^{\circledR}$, Merial; Silirum: Silirum ${ }^{\mathbb{B}}$, CZ Veterinaria/Pfizer; Lio-Johne, Ovejero, Spain; Gudair: Gudair ${ }^{\mathbb{B}}$, CZ Veterinaria/Pfizer; Rec: recombinant; CWD Cell Wall Deficient MAP; CWC Cell Wall Competent MAP; P/O/P Paraffin, Olive Oil, Pumice Stone Powder; y: year(s); m: month(s); w: week(s); d: day(s); F: Field trial; E:

Experimental infection; MC: Comparison to matched controls; IF: Comparison of initial versus final prevalence; NVH: Comparison to non-vaccinating herds; TC: Tissue culture; FC: Fecal Culture. 
Table 5 Pathogenetic effects (histopathological lesions).

\begin{tabular}{|c|c|c|c|c|c|c|c|c|c|}
\hline \multicolumn{4}{|c|}{ Vaccine } & \multirow[t]{2}{*}{ Country and reference } & \multirow[t]{2}{*}{ Year } & \multirow[t]{2}{*}{ Number of animals } & \multirow[t]{2}{*}{ Age at vaccination } & \multirow[t]{2}{*}{ Reduction (\%) } & \multirow[t]{2}{*}{ Type of trial } \\
\hline Name/Laboratory & Type & Strain/Antigen & Adjuvant & & & & & & \\
\hline \multicolumn{10}{|c|}{ Cattle } \\
\hline NCV & Live & 6 strains & Oil & U.S.A. [65] & 1935 & 20 & calves & 42.86 & $\mathrm{E}, \mathrm{HP}$ \\
\hline NCV & Live & avirulent & $\mathrm{P} / \mathrm{O} / \mathrm{P}$ & U.S.A. [83] & 1974 & 16 & $16 d$ & 17.24 & $\mathrm{E}, \mathrm{HP}$ \\
\hline Lelystad & Killed & - & None & Netherlands [71] & 1992 & 3209 & $1 \mathrm{~m}$ & 58.34 & $F, I F, H P$ \\
\hline NCV & Killed & - & Oil & Netherlands [72] & 1994 & 499 & $1 \mathrm{~m}$ & 57.23 & $F, I F, H P$ \\
\hline NCV & Killed & - & Oil & Netherlands [37] & 1996 & 573 & $1 \mathrm{~m}$ & 58.09 & $F, I F, H P$ \\
\hline Silirum & Killed & $316 \mathrm{~F}$ & Oil & Spain [103] & 2005 & 79 & all ages & 38.68 & $F, M C, H P$ \\
\hline Silirum & Killed & $316 \mathrm{~F}$ & Oil & Spain [90] & 2005 & 14 & $2 \mathrm{~m}$ & 37.50 & E, MC, HP \\
\hline \multicolumn{8}{|c|}{ Average } & \multicolumn{2}{|c|}{$57.54 \pm 0.11$} \\
\hline \multicolumn{10}{|c|}{ Sheep } \\
\hline NCV & Killed & - & Oil & Iceland [54] & 1960 & 419 & $3 \mathrm{~m}$ & 83.58 & $F, M C, P M$ \\
\hline NCV & Killed & - & Oil & Iceland [54] & 1960 & 24323 & $3 \mathrm{~m}$ & 93.55 & $\mathrm{~F}, \mathrm{MC}, \mathrm{PM}$ \\
\hline NCV & Killed & & Oil & U.K. [95] & 1962 & 126 & $1 \mathrm{~m}$ & 52.22 & $\mathrm{E}, \mathrm{MC}, \mathrm{HP}$ \\
\hline Lio-Johne & Live & $316 \mathrm{~F}$ & Oil & Spain [74] & 1993 & 570 & $1 \mathrm{~m}$ & 100.00 & $F, M C, H P$ \\
\hline Lio-Johne & Live & $316 \mathrm{~F}$ & Oil & Spain [74] & 1993 & 1201 & Adults & 53.36 & $F, M C, H P$ \\
\hline Neoparasec & Live & $316 \mathrm{~F}$ & Oil & Spain [96] & 1994 & 13 & $2 \mathrm{~m}$ & 64.52 & $E, M C, H P$ \\
\hline Neoparasec & Live & $316 \mathrm{~F}$ & Oil & Australia [104] & 1995 & 475 & $3 \mathrm{~m}$ & 82.27 & F, MC. HP \\
\hline Neoparasec \& Gudair & Live and Killed & $316 \mathrm{~F}$ & Oil & Spain [77] & 1995 & 135 & Adults & -3.03 & $F, I F, H P$ \\
\hline Neoparasec & Live & $316 \mathrm{~F}$ & Oil & New Zealand [78] & 2000 & 28 & $1-1.5 \mathrm{~m}$ & 77.78 & $\mathrm{E}, \mathrm{MC}, \mathrm{HP}$ \\
\hline Gudair & Killed & $316 \mathrm{~F}$ & Oil & Spain [105] & 2002 & 12 & $1 \mathrm{~m}$ & 100.00 & $\mathrm{E}, \mathrm{MC}, \mathrm{HP}$ \\
\hline Mycopar & Killed & $\begin{array}{c}\text { M.a.a. } \\
\text { Strain } 18\end{array}$ & Oil & U.S.A. [106] & 2005 & 178 & $60-164 d$ & 75.31 & $\mathrm{~F}, \mathrm{MC}, \mathrm{HP}$ \\
\hline Neoparasec & Live & $316 F$ & Oil & New Zealand [57] & 2005 & 59 & $2-4 w$ & 68.52 & $\mathrm{E}, \mathrm{MC}, \mathrm{HP}$ \\
\hline AquaVax & Live & $316 \mathrm{~F}$ & saline & New Zealand [57] & 2005 & 58 & $2-4 w$ & -2.48 & $\mathrm{E}, \mathrm{MC}, \mathrm{HP}$ \\
\hline Gudair & Killed & $316 \mathrm{~F}$ & Oil & Australia [34] & 2006 & 88 & $1-3 m$ & 72.70 & $\mathrm{~F}, \mathrm{MC}, \mathrm{GL}, \mathrm{HP}$ \\
\hline Gudair & Killed & $316 \mathrm{~F}$ & Oil & Australia [34] & 2006 & 307 & $1-3 m$ & 48.29 & $\mathrm{~F}, \mathrm{MC}, \mathrm{GL}, \mathrm{HP}$ \\
\hline Gudair & Killed & $316 \mathrm{~F}$ & Oil & New Zealand [81] & 2009 & 62 & $4 \mathrm{~m}$ & 75.57 & $\mathrm{E}, \mathrm{MC}, \mathrm{HP}$ \\
\hline NCV & Killed & $316 \mathrm{~F}$ & Lipid-K formulation & New Zealand [81] & 2009 & 63 & $4 \mathrm{~m}$ & 37.17 & $E, M C, H P$ \\
\hline NCV & Live & $316 \mathrm{~F}$ & Lipid-K formulation & New Zealand [81] & 2009 & 63 & $4 \mathrm{~m}$ & 51.32 & $\mathrm{E}, \mathrm{MC}, \mathrm{HP}$ \\
\hline NCV & Live & $316 \mathrm{~F}$ & Lipid-K formulation & New Zealand [81] & 2009 & 62 & $4 \mathrm{~m}$ & 57.56 & $\mathrm{E}, \mathrm{MC}, \mathrm{HP}$ \\
\hline \multicolumn{8}{|c|}{ Average } & \multicolumn{2}{|c|}{$89.70 \pm 0.15$} \\
\hline \multicolumn{10}{|c|}{ Goats } \\
\hline NCV & Live & $2 \mathrm{E} / 316 \mathrm{~F}$ & $\mathrm{P} / \mathrm{O} / \mathrm{P}$ & Norway [26] & 1985 & 5535 & $1 \mathrm{~m}$ & 97.18 & $F, I F, P M$ \\
\hline Gudair & Killed & $316 \mathrm{~F}$ & Oil & Spain [38] & 2000 & 189 & Adults & 65.88 & $\mathrm{~F}, \mathrm{MC}, \mathrm{HP}$ \\
\hline NCV & Killed & Goat isolate (CWD) & QS21 & U.S.A. [102] & 2007 & 20 & $1 \mathrm{w}$ & 34.38 & $\mathrm{E}, \mathrm{MC}, \mathrm{HP}$ \\
\hline NCV & Killed & Goat isolate (CWC) & QS21 & U.S.A. [102] & 2007 & 20 & $1 \mathrm{w}$ & 32.03 & $\mathrm{E}, \mathrm{MC}, \mathrm{HP}$ \\
\hline
\end{tabular}


Table 5 Pathogenetic effects (histopathological lesions). (Continued)

\begin{tabular}{|c|c|c|c|c|c|c|c|c|c|}
\hline $\mathrm{NCV}$ & Killed & Goat isolate (CWC) & Alum & U.S.A. [102] & 2007 & 20 & $1 \mathrm{w}$ & 44.53 & $\mathrm{E}, \mathrm{MC}, \mathrm{HP}$ \\
\hline NCV & Killed & Goat isolate (CWD) & Alum & U.S.A. [102] & 2007 & 20 & $1 \mathrm{w}$ & -17.19 & $\mathrm{E}, \mathrm{MC}, \mathrm{HP}$ \\
\hline NCV & Killed & Virulent Field Strain & Alum & India [48] & 2007 & 8 & $4-6 m$ & 75.00 & $\mathrm{E}, \mathrm{MC}, \mathrm{HP}$ \\
\hline Gudair & Killed & $316 \mathrm{~F}$ & Oil & India [48] & 2007 & 8 & $4-6 m$ & 50.00 & $\mathrm{E}, \mathrm{MC}, \mathrm{HP}$ \\
\hline NCV & $\operatorname{Rec}$ & $\operatorname{MAP}(85 \mathrm{~A}, 85 \mathrm{~B}, \mathrm{SOD}, 74 \mathrm{~F})$ & DDA & U.S.A. [40] & 2009 & 17 & $5-10 d$ & 66.67 & $\mathrm{E}, \mathrm{MC}, \mathrm{HP}$ \\
\hline NCV & $\operatorname{Rec}$ & $\operatorname{MAP}(85 \mathrm{~A}, 85 \mathrm{~B}, \mathrm{SOD}, 74 \mathrm{~F})$ & none & U.S.A. [40] & 2009 & 17 & $5-10 d$ & 33.33 & E, MC, HP \\
\hline
\end{tabular}

NCV: non-commercial vaccine; Lelystad: Central Veterinary Institute, Lelystad, The Netherlands; Silirum: Silirum ${ }^{\circledR}$, CZ Veterinaria/Pfizer; Lio-Johne, Ovejero, Spain; Neoparasec: Neoparasec ${ }^{\circledR}$, Merial; Gudair: Gudair ${ }^{\circledR}$, CZ Veterinaria/Pfizer; Mycopar ${ }^{\circledR}$ : Mycopar Fort Doge/Solvay, USA; AquaVax; Rec: recombinant; CWD Cell Wall Deficient MAP; CWC Cell Wall Competent MAP; P/O/P Paraffin, Olive Oil, Pumice Stone Powder; y: year(s); m: month(s); w: week(s); d: day(s); F: Field trial; E: Experimental infection; MC: Comparison to matched controls; IF: Comparison of initial versus final prevalence; GL: Gross lesions; HL: Histological lesions. 


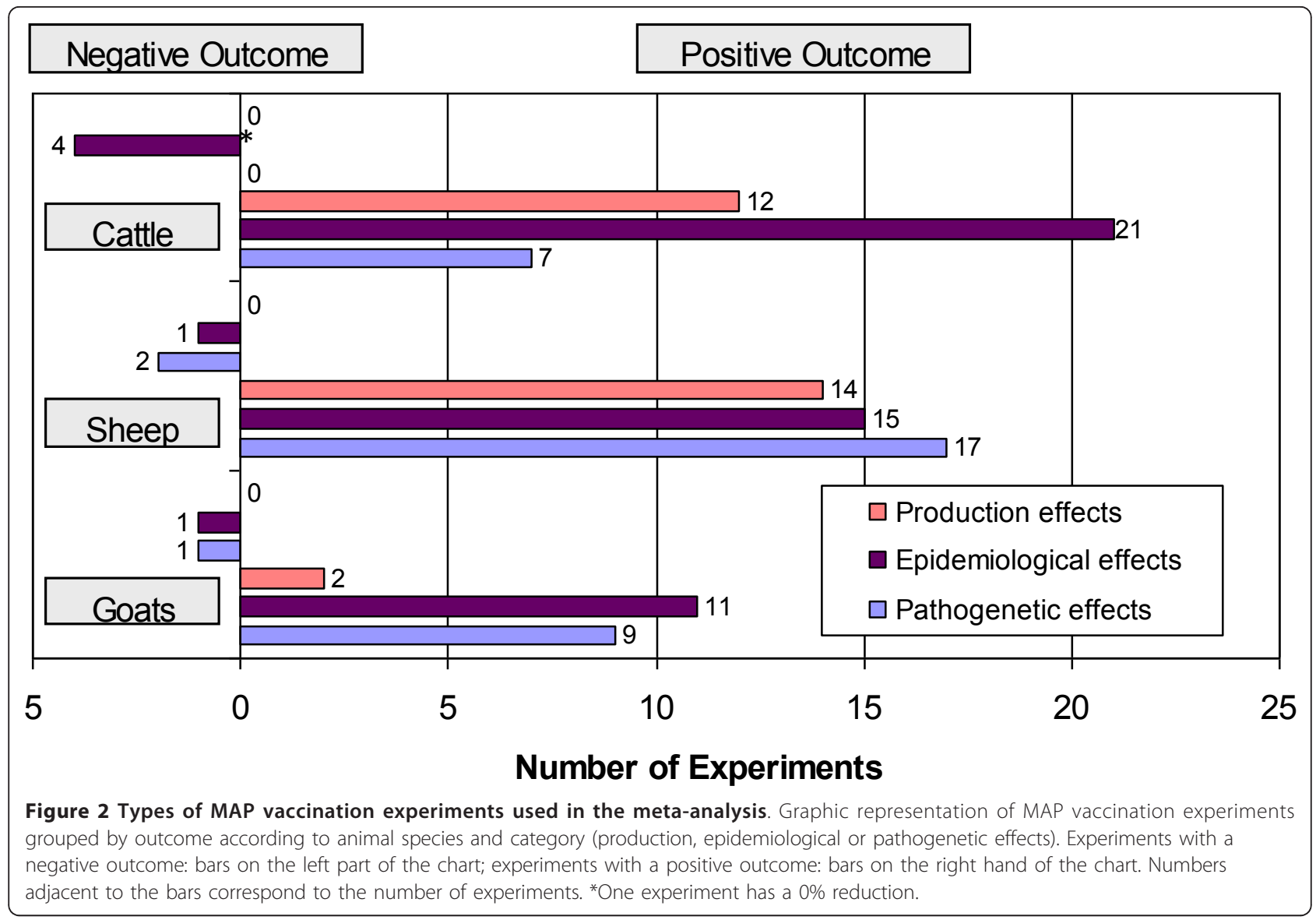

paratuberculosis culling rates, since measurement of the other variables is much more time-consuming and costly. This is also reflected in the median sample size for the studies that looked at the production variable, 876, 700, and 4975 animals for cattle, sheep and goat studies, respectively, while studies analyzing the epidemiological or pathogenetic variables had median sizes around 100 or less.

The range of study length was between a few months and 16 years covering a period of 74 years. A large increase in sheep studies in the last decade coincided with the availability of the successful small ruminant commercial vaccine Gudair ${ }^{\mathrm{TM}}$ and its extended application in Australia and New Zealand. In the majority of the studies (68 experiments) killed vaccines were used. Most experiments used MAP strain 316F from Weybridge, nine used Strain 18 (now known to be $M$. avium subsp. avium rather than MAP [56]), and the rest used local isolates or subunit vaccines consisting of recombinant proteins. Not surprisingly, $316 \mathrm{~F}$ is the most frequently used strain in sheep studies, since the above mentioned commercial vaccine for sheep and goats is based on this strain. Bacterial content varied widely, from $1000 \mathrm{CFU}$ to $3 \times 10^{9} \mathrm{CFU}$, and from $2.5 \mathrm{mg}$ to $100 \mathrm{mg}$. The large majority of studies used some type of oily adjuvant (mineral oil, olive oil, liquid paraffin etc.) and in very few cases alum. In one study [57], AquaVax experimental vaccine was used, which contains no adjuvant but saline instead. More recent studies have started using other newer adjuvants such as MPLA, RIBI, cytokines, DDA, QS21, and lipid formulations, some of them with good results.

\section{Discussion}

A wide variation in the efficacy of vaccines was observed, especially in cattle and sheep, where negative reductions are described in some studies. However, the overall results are pretty homogeneous, with very small error ranges due to the large numbers of observations included. In general, vaccine strain or administration route differences do not seem to substantially alter the outcome of vaccination, however, type of antigen formulation or adjuvant appears to have been important in a few experimental studies where different formulations were compared side by side [58].

The goal of this review was to evaluate vaccination as a whole, summarizing the results into a single table for each type of measure used to determine vaccine success. This analysis has revealed that, in average, vaccination 
has a positive effect. However, since the efficacy figures are rather poor in comparison to vaccines for other microorganisms, it is relevant to at least try to discuss possible reasons for some of the low success rates. In order to simplify, one possible approach is to find an explanation for studies where vaccination performed below the average. Production effect studies where the measurement was total mortality may be considered flawed because in most cases mortality did not differentiate between paratuberculosis and other pathologies, possibly diluting the "vaccine effect". This is evident in the case of sheep and goat trials were adults were considered. Since the more sensitive part of the population might have already died of paratuberculosis before vaccination the remaining animals could be considered more resistant to paratuberculosis, and therefore, less likely to show any effect of vaccine protection. Because young animal studies showed larger effects, this becomes a very likely explanation for low reduction rates. An additional explanation for the poor results could be the fact that, frequently, vaccination programs coincide with the initiation of other control measures making it difficult to assess the real effect of the vaccine on paratuberculosis control.

Under the epidemiological effects analyzed, reduction in the proportion of fecal shedders appears to be one of the measurements showing the widest variability. This happens mostly in small studies or in studies carried out in the Netherlands. Besides the qualitative effects in terms of protection conferred, vaccination should be assessed from another, perhaps even more important standpoint, such as is the reduction of amounts of bacteria shed by vaccinated and non-vaccinated animals.

When considering reduction in pathogenetic effects, it should be pointed out that some of the studies had a very short follow up and that the presence of focal lesions of paratuberculosis are weighted the same as the presence of large areas of affected intestine.

Since the vast majority of the studies show a positive effect, the question as to why vaccination has not been given more opportunities comes out with force. Especially, because for years MAP eradication efforts have only shown very moderate success or straight failure due to their enormous costs and frequent relapses of infected animals. Already in the eighties [59] and nineties [37,60] several studies showed the profitability of vaccination. Over a period of a few years, the economic advantages of vaccination may be up 20 times higher than any testing and culling strategy which, in addition to yielding uncertain results, it results in a much higher economic cost. Other strategies based on certification are compatible with vaccination, and moreover, vaccination might allow a spectrum of other approaches to paratuberculosis control dependant on the financial resources of the farm, region or farmers association, and the actual economic losses sustained by the enterprise. It has been estimated that only a $5 \%$ annual clinical incidence of paratuberculosis will justify entering a mixed vaccination and testing and culling strategy [61].

In our opinion, there is a mixture of vested interests on control programs based in testing and culling, simplistic thinking comparing tuberculosis and paratuberculosis, fear of cross-reactions, academic detachment and confusion between ideal objectives and practical needs for the livestock industry. It is clear that the main reason for the opposition to MAP vaccination in cattle has been the problem of expected interference with the diagnosis of tuberculosis and its consequences in trade and national TB programs, however, the availability of an OIE official test -the comparative intradermal tuberculin test- that can very easily solve this problem in the majority of cases, should eliminate this concern on MAP vaccination in cattle. Recent field vaccination trials in cattle with an experimental MAP vaccine (Silirum ${ }^{\mathrm{TM}}, \mathrm{CZV}$ ), have shown that less than $0.5 \%$ of vaccinated animals will give interference problems when the comparative intradermal tuberculin test is used even if the most restrictive interpretation of results proposed by the OIE is applied (Joseba Garrido, personal communications). The benefits obtained from production increases and reduction in clinical cases of MAP, will largely outweigh the small loss due to culling of these tuberculosis cross-reactive animals. In addition, new plans for the introduction of improved tuberculosis vaccines for cattle [62], will also affect the prospects of MAP vaccination in cattle, since the accompanying DIVA diagnostic test will probably allow for the identification of MAP infected or vaccinated animals.

MAP vaccination concerns in cattle have been further aggravated by the fear of the dairy industry to a crisis of confidence in their products, particularly, if a potential zoonotic link between paratuberculosis and a human disease (IBD/Crohn's disease) is confirmed [63] or if too much discussion and research efforts are focused on this subject. At this moment in which the paratuberculosis scientific community has finally accepted that the key to the paratuberculosis problem might not be eradication, but just control, vaccination offers the solution to this problem, since it not only allows to confine the paratuberculosis problem within the limits of a livestock production issue, while downright calming the worries of farmers, but also provides the perfect cover for doing something against paratuberculosis from a Public Health point of view, without incurring in massive costs. Vaccination might be the beginning of the end of the huge worldwide paratuberculosis problem and might mark the difference between doing nothing and advancing towards global control [64]. 


\section{Conclusions}

Paratuberculosis control poses a though challenge for farmers and veterinarians. Test and cull strategies can be useful in some settings but do not seem to have reached extensive success. Control by vaccination is an alternative that has been longtime in use in some regions and species. A substantial number of vaccination studies where objective information is amenable to meta-analysis treatment have been published in peer reviewed journals or in conference proceedings or other media. The high heterogeneity among reports makes it difficult to accept that the narrow statistical confidence interval obtained in these meta-analyses actually represents the true range of reduction in the whole set of trials. However, the results analyzed here clearly show a general positive effect from vaccination, negative effects only in a few trials, and a positive average balance according to all three variables considered (production, epidemiological or pathogenetic effects). In terms of quantitative reduction, the minimum is an $11 \%$ reduction in MAP isolation, which could be considered the worst case average, but with a common outcome at over $50 \%$ which is highly profitable from a production point of view. This strategy thus has high chances of have a effect on the overall environmental contamination with MAP, which would mean a significant advance in the fight against paratuberculosis, both in the animal and in the (potential) human public health fields.

\section{Abbreviations \\ CC: Clinical Cases; CWC: Cell Wall Competent; CWD: Cell Wall Deficient; E: Experimental infection; F: Field trial; FC: Fecal culture; GL: Gross lesions; HL: Histological lesions; IBD: Inflammatory Bowel Disease; IF: Comparison of initial versus final prevalence; MAP: Mycobacterium avium subsp. paratuberculosis; MC: Comparison to matched controls; NCV: Non- commercial vaccine; $\mathrm{NVH}$ : Comparison to non-vaccinating herds; PCR: Polymerase Chain Reaction; PPDbov: Purified Protein Derivative from Mycobacterium bovis; PPDav: Purified Protein Derivative from Mycobacterium avium subsp. avium; P/O/P: Paraffin, Olive Oil, Pumice Stone Powder; Rec: Recombinant; TC: Tissue culture; TM: Total mortality, PCR: Polymerase Chain Reaction, MAP: Mycobacterium avium subsp. Paratuberculosis; IBD: Inflammatory Bowel Disease.}

\section{Author details \\ ${ }^{1}$ Vacunek, Bizkaiko Teknologia Parkea, Ibaizabal Bidea 800, Derio 48160, Bizkaia, Spain. ${ }^{2}$ NEIKER-Tecnalia, Department of Animal Health, Berreaga 1, 48160 Derio, Bizkaia, Spain.}

\section{Authors' contributions}

RAJ conceived of the study and performed the statistical analysis. Both authors (FB and RAJ) participated in the design of the study, acquisition of data and helped to draft the manuscript. Both read and approved the final manuscript.

\section{Competing interests}

Felix Bastida works for Vacunek, a small animal health biotechnology company. He is currently working on the development of a new paratuberculosis vaccine for cattle in collaboration with NEIKER and CZ Veterinaria, the producer of Gudair ${ }^{\oplus}$, a commercial paratuberculosis vaccine for use in sheep and goats.
Ramon A. Juste works for a Regional Government funded Agricultural Research Institute that receives funding for research projects from local, regional, national and European Governments, as well as, from companies such as CZ Veterinaria and Vacunek.

Received: 18 May 2011 Accepted: 31 October 2011

Published: 31 October 2011

\section{References}

1. Chiodini RJ, Van Kruiningen HJ, Merkal RS: Ruminant paratuberculosis (Johne's disease): the current status and future prospects. Cornell Vet 1984, 74:218-262.

2. Chiodini RJ, Van Kruiningen HJ: Eastern white-tailed deer as a reservoir of ruminant paratuberculosis. J Am Vet Med Assoc 1983, 182:168-169.

3. Manning EJ: Mycobacterium avium subspecies paratuberculosis: a review of current knowledge. J Zoo Wildl Med 2001, 32:293-304.

4. Pickup RW, Rhodes G, Bull TJ, Arnott S, Sidi-Boumedine K, Hurley M, Hermon-Taylor J: Mycobacterium avium subsp. paratuberculosis in lake catchments, in river water abstracted for domestic use, and in effluent from domestic sewage treatment works: diverse opportunities for environmental cycling and human exposure. Appl Environ Microbiol 2006, 72:4067-4077.

5. Stop the cull. Animal vaccines prevent disease but founder because of political motivations. Nat Biotechnol 2007, 25:1329.

6. Torgerson P, Torgerson D: Benefits of stemming bovine TB need to be demonstrated. Nature 2009, 457:657.

7. Rossiter CA, Burhans WS: Farm-specific approach to paratuberculosis (Johne's disease) control. Vet Clin North Am Food Anim Pract 1996, 12:383-415.

8. Goodger WJ, Collins MT, Nordlund KV, Eisele C, Pelletier J, Thomas CB, Sockett DC: Epidemiologic study of on-farm management practices associated with prevalence of Mycobacterium paratuberculosis infections in dairy cattle. J Am Vet Med Assoc 1996, 208:1877-1881.

9. Whittington RJ, Marshall DJ, Nicholls PJ, Marsh IB, Reddacliff LA: Survival and dormancy of Mycobacterium avium subsp. paratuberculosis in the environment. Appl Environ Microbiol 2004, 70:2989-3004.

10. Whittington RJ, Marsh IB, Reddacliff LA: Survival of Mycobacterium avium subsp. paratuberculosis in dam water and sediment. Appl Environ Microbiol 2005, 71:5304-5308.

11. Muskens J, Elbers AR, van Weering HJ, Noordhuizen JP: Herd management practices associated with paratuberculosis seroprevalence in Dutch dairy herds. J Vet Med B Infect Dis Vet Public Health 2003, 50:372-377.

12. Kudahl AB, Sorensen JT, Nielsen SS, Ostergaard S: Simulated economic effects of improving the sensitivity of a diagnostic test in paratuberculosis control. Prev Vet Med 2007, 78:118-129.

13. Zimmer K, Drager KG, Klawonn W, Hess RG: Contribution to the diagnosis of Johne's disease in cattle. Comparative studies on the validity of ZiehlNeelsen staining, faecal culture and a commercially available DNA-Probe test in detecting Mycobacterium paratuberculosis in faeces from cattle. Zentralb/ Veterinarmed B 1999, 46:137-140.

14. Whitlock RH, Wells SJ, Sweeney RW, Van Tiem J: ELISA and fecal culture for paratuberculosis (Johne's disease): sensitivity and specificity of each method. Vet Microbiol 2000, 77:387-398.

15. Aly S, Anderson R, Gardner I, Whitlock R, Fyock T, Adaska J: Comparison of methods for detection of MAP super-shedder cows in a large dairy herd. Johnes Disease Integrated Program (JDIP) Annual Meeting; Michigan 2008.

16. Collins MT, Gardner IA, Garry FB, Roussel AJ, Wells SJ: Consensus recommendations on diagnostic testing for the detection of paratuberculosis in cattle in the United States. J Am Vet Med Assoc 2006, 229:1912-1919.

17. Alinovi CA, Ward MP, Lin TL, Wu CC: Sample handling substantially affects Johne's ELISA. Prev Vet Med 2009, 90:278-283.

18. Garrido JM, Aduriz G, Geijo MV, Sevilla I, Juste RA: Comparison of different indirect ELISA methods on reference cattle. In Proceedings of 7th International Colloquium on Paratuberculosis; June 11-14, 2002; Bilbao, Spain. Edited by: Juste RA. International Association for Paratuberculosis; 2002:52-53.

19. Dieguez FJ, Gonzalez AM, Menendez S, Vilar MJ, Sanjuan ML, Yus E, Arnaiz I: Evaluation of four commercial serum ELISAs for detection of Mycobacterium avium subsp. paratuberculosis infection in dairy cows. Vet J 2009, 180:231-235. 
20. Alinovi CA, Ward MP, Lin TL, Moore GE, Wu CC: Real-time PCR, compared to liquid and solid culture media and ELISA, for the detection of Mycobacterium avium ssp. paratuberculosis. Vet Microbiol 2009, 136:177-179.

21. Wells SJ, Collins MT, Faaberg KS, Wees C, Tavornpanich S, Petrini KR, Collins JE, Cernicchiaro N, Whitlock RH: Evaluation of a rapid fecal PCR test for detection of Mycobacterium avium subsp. paratuberculosis in dairy cattle. Clin Vaccine Immunol 2006, 13:1125-1130.

22. Bannantine JP, Baechler E, Zhang Q, Li L, Kapur V: Genome scale comparison of Mycobacterium avium subsp. paratuberculosis with Mycobacterium avium subsp. avium reveals potential diagnostic sequences. J Clin Microbiol 2002, 40:1303-1310.

23. Poupart $P$, Coene M, Van Heuverswyn H, Cocito C: Preparation of a specific RNA probe for detection of Mycobacterium paratuberculosis and diagnosis of Johne's disease. J Clin Microbiol 1993, 31:1601-1605.

24. Irenge LM, Walravens K, Govaerts M, Godfroid J, Rosseels V, Huygen K Gala JL: Development and validation of a triplex real-time PCR for rapid detection and specific identification of $\mathrm{M}$. avium sub sp. paratuberculosis in faecal samples. Vet Microbiol 2009, 136:166-172.

25. Lu Z, Mitchell RM, Smith RL, Van Kessel JS, Chapagain PP, Schukken YH, Grohn YT: The importance of culling in Johne's disease control. J Theor Biol 2008, 254:135-146.

26. Saxegaard F, Fodstad FH: Control of paratuberculosis (Johne's disease) in goats by vaccination. Vet Rec 1985, 116:439-441.

27. Fridriksdottir V, Gunnarsson E, Sigurdarson S, Gudmundsdottir KB: Paratuberculosis in Iceland: epidemiology and control measures, past and present. Vet Microbiol 2000, 77:263-267.

28. Barry C, Corbett D, Bakker D, Andersen P, McNair J, Strain S: The Effect of Mycobacterium avium Complex Infections on Routine Mycobacterium bovis Diagnostic Tests. Vet Med Int 2011, 145092.

29. Eppleston J, Windsor PA: Lesions attributed to vaccination of sheep with Gudair for the control of ovine paratuberculosis: post farm economic impacts at slaughter. Aust Vet J 2007, 85:129-133.

30. Chiodini R: Age resistance and the reticular groove reflex: link or coincidence? The Paratuberculosis Newsletter 1993, 5:29-30.

31. Perez Perez V: Estudio de la paratuberculosis en la especie ovina. University of Zaragoza, Spain; 1993.

32. Chavez Gris G: Estudio comparativo de las lesiones y de la respuesta inmunologica observada en corderos infectados experimentalmente con Mycobacterium paratuberculosis y de Mycobacterium avium sp. silvaticum. University of Zaragoza, Spain; 1993.

33. Stabel JR, Palmer MV, Harris B, Plattner B, Hostetter J, Robbe-Austerman S: Pathogenesis of Mycobacterium avium subsp. paratuberculosis in neonatal calves after oral or intraperitoneal experimental infection. Vet Microbiol 2009, 136:306-313.

34. Reddacliff $L$, Eppleston J, Windsor P, Whittington R, Jones S: Efficacy of a killed vaccine for the control of paratuberculosis in Australian sheep flocks. Vet Microbiol 2006, 115:77-90.

35. Benedictus A, Mitchell RM, Linde-Widmann M, Sweeney R, Fyock T, Schukken YH, Whitlock RH: Transmission parameters of Mycobacterium avium subspecies paratuberculosis infections in a dairy herd going through a control program. Prev Vet Med 2008, 83:215-227.

36. Perez V, Tellechea J, Corpa JM, Gutierrez M, Garcia Marin JF: Relation between pathologic findings and cellular immune responses in sheep with naturally acquired paratuberculosis. Am J Vet Res 1999, 60:123-127.

37. van Schaik G, Kalis CH, Benedictus G, Dijkhuizen AA, Huirne RB: Costbenefit analysis of vaccination against paratuberculosis in dairy cattle. Vet Rec 1996, 139:624-627.

38. Corpa JM, Perez V, Sanchez MA, Marin JF: Control of paratuberculosis (Johne's disease) in goats by vaccination of adult animals. Vet Rec 2000 146:195-196.

39. Koets A, Hoek A, Langelaar M, Overdijk M, Santema W, Franken P, Eden W, Rutten V: Mycobacterial $70 \mathrm{kD}$ heat-shock protein is an effective subunit vaccine against bovine paratuberculosis. Vaccine 2006, 24:2550-2559.

40. Kathaperumal K, Kumanan V, McDonough S, Chen LH, Park SU, Moreira MA Akey B, Huntley J, Chang CF, Chang YF: Evaluation of immune responses and protective efficacy in a goat model following immunization with a coctail of recombinant antigens and a polyprotein of Mycobacterium avium subsp. paratuberculosis. Vaccine 2009, 27:123-135

41. Velaz-Faircloth M, Cobb AJ, Horstman AL, Henry SC, Frothingham R: Protection against Mycobacterium avium by DNA vaccines expressing mycobacterial antigens as fusion proteins with green fluorescent protein. Infect Immun 1999, 67:4243-4250.

42. Sechi LA, Mara L, Cappai P, Frothingam R, Ortu S, Leoni A, Ahmed N, Zanetti S: Immunization with DNA vaccines encoding different mycobacterial antigens elicits a Th1 type immune response in lambs and protects against Mycobacterium avium subspecies paratuberculosis infection. Vaccine 2006, 24:229-235.

43. Kadam M, Shardul S, Bhagath JL, Tiwari V, Prasad N, Goswami PP: Coexpression of $16.8 \mathrm{kDa}$ antigen of Mycobacterium avium paratuberculosis and murine gamma interferon in a bicistronic vector and studies on its potential as DNA vaccine. Vet Res Commun 2009, 33:597-610.

44. Roupie V, Leroy B, Rosseels V, Piersoel V, Noel-Georis I, Romano M, Govaerts M, Letesson JJ, Wattiez R, Huygen K: Immunogenicity and protective efficacy of DNA vaccines encoding MAP0586c and MAP4308c of Mycobacterium avium subsp. paratuberculosis secretome. Vaccine 2008, 26:4783-4794.

45. Park SU, Kathaperumal K, McDonough S, Akey B, Huntley J, Bannantine JP, Chang YF: Immunization with a DNA vaccine cocktail induces a Th1 response and protects mice against Mycobacterium avium subsp. paratuberculosis challenge. Vaccine 2008, 26:4329-4337.

46. Bull TJ, Gilbert SC, Sridhar S, Linedale R, Dierkes N, Sidi-Boumedine K, Hermon-Taylor J: A novel multi-antigen virally vectored vaccine against Mycobacterium avium subspecies paratuberculosis. PLOS ONE 2007, 2: e1229.

47. Huntley JF, Stabel JR, Paustian ML, Reinhardt TA, Bannantine JP: Expression library immunization confers protection against Mycobacterium avium subsp. paratuberculosis infection. Infect Immun 2005, 73:6877-6884.

48. Singh SV, Singh PK, Singh AV, Sohal JS, Gupta VK, Vihan VS: Comparative efficacy of an indigenous 'inactivated vaccine' using highly pathogenic field strain of Mycobacterium avium subspecies paratuberculosis 'Bison type' with a commercial vaccine for the control of Capriparatuberculosis in India. Vaccine 2007, 25:7102-7110.

49. Juste RA, Alonso-Hearn M, Molina E, Geijo M, Vazquez P, Sevilla IA, Garrido JM: Significant reduction in bacterial shedding and improvement in milk production in dairy farms after the use of a new inactivated paratuberculosis vaccine in a field trial. BMC Res Notes 2009, 2:233.

50. Windsor P: Research into vaccination against ovine Johne's disease in Australia. Small Ruminant Research 2006, 62:139-142.

51. Emery DL, Whittington RJ: An evaluation of mycophage therapy, chemotherapy and vaccination for control of Mycobacterium avium subsp. paratuberculosis infection. Vet Microbiol 2004, 104:143-155.

52. Rosseels V, Huygen K: Vaccination against paratuberculosis. Expert ReV Vaccines 2008, 7:817-832.

53. Vallee H, R P: Etudes sur l'enterite paratuberculeuse des bovides (note preliminaire). Rev Gen Med Vet 1926, 35:1-9.

54. Sigurdsson B: A killed vaccine against paratuberculosis (Johne's disease) in sheep. Am J Vet Res 1960, 21:54-67.

55. Domenech JM: Bioestadística Métodos Estadísticos Para Investigadores. In Temas Fundamentales de Psicología.. 4 edition. Edited by: Massons 1. Barcelona; 1982:.

56. Chiodini RJ: Abolish Mycobacterium paratuberculosis strain 18. J Clin Microbiol 1993, 31:1956-1958.

57. Begg DJ, Griffin JF: Vaccination of sheep against M. paratuberculosis: immune parameters and protective efficacy. Vaccine 2005, 23:4999-5008.

58. Uzonna JE, Chilton P, Whitlock RH, Habecker PL, Scott P, Sweeney RW: Efficacy of commercial and field-strain Mycobacterium paratuberculosis vaccinations with recombinant IL-12 in a bovine experimental infection model. Vaccine 2003, 21:3101-3109.

59. Benedictus G, Dinkla ETB, Wentink GH: Preliminary results of vaccination against paratuberculosis in adult dairy cattle. In Proceedings International Colloquium on Paratuberculosis, Il; Laboratoire Central de Recherches Veterinaires, Maisons-Alfort, France. Edited by: Thorel MF, Merkal RS. International Association for Paratuberculosis; 1988:136-140.

60. Juste RA, Casal J: An economic and epidemiologic simulation of different control strategies for ovine paratuberculosis. Prev Vet Med 1993, 15:101-115.

61. Argenté G: Utilisation de la culture fecale dans un plan de prevention de la paratuberculose dans 500 tropeaux; Justifications techniques et economiques. In Proceedings of the International Colloquium on Paratuberculosis, II; Laboratoire Central de Recherches Veterinaires. Maisons- 
Alfort. France. Edited by: Thorel MF, Merkal RS. International Association for Paratuberculosis; 1988:30-35.

62. Vordermeier M, Gordon SV, Hewinson RG: Mycobacterium bovis antigens for the differential diagnosis of vaccinated and infected cattle. Vet Microbiol 2011, 151:8-13.

63. Possible links between Crohn's disease and Paratuberculosis. Book Possible links between Crohn's disease and Paratuberculosis 2000, SANCO/B3/ R16/2000. EUROPEAN COMMISSION DIRECTORATE-GENERAL HEALTH \& CONSUMER PROTECTION Directorate B - Scientific Health Opinions Unit B3 - Management of scientific committees II.

64. Juste RA, Geijo MV, Sevilla I, Aduriz G, Garrido JM: Control of paratuberculosis by vaccination. In Proceedings of the 7th International Colloquium on Paratuberculosis; Bilbao, Spain. Edited by: Juste RA. International Association for Paratuberculosis; 2002:331.

65. Hagan WA: Vaccination against Johne's disease. Cornell Vet 1935, 25:344-353.

66. Doyle TM: Johne's disease. In Infectious Diseases of Animals. Volume 1. Edited by: I.A. SAWaG. London: Butterworth's Scientific Publications; 1959:319-345.

67. Doyle TM: Vaccination against Johne's disease. Vet Rec 1964, 76:73-76.

68. Stuart P: Vaccination against Johne's Disease in Cattle Exposed to Experimental Infection. Br Vet J 1965, 121:289-318.

69. Wilesmith JW: Johne's disease: a retrospective study of vaccinated herds in Great Britain. Br Vet J 1982, 138:321-331.

70. Hurley S, Ewing E: Results of a field evaluation of a whole cell bacterin. In Proceedings of the International Colloquium on Paratuberculosis, I; NADC, USDA, Ames, IA, USA. Edited by: Merkal RS. International Association for Paratuberculosis; 1983:244-248.

71. Kalis $\mathrm{CHJ}$, Benedictus $\mathrm{G}$, van Weering HJ, Flamand F, Haagsma J: Experiences with the use of an experimental vaccine in the control of paratuberculosis in The Netherlands. In Proceedings of the 3rd International Colloquium on Paratuberculosis; Providence, RI, USA. Edited by: Chiodini RJ, Kreeger JM. International Association for Paratuberculosis; 1992:484-494.

72. Wentink GH, Bongers JH, Zeeuwen AA, Jaartsveld FH: Incidence of paratuberculosis after vaccination against $M$. paratuberculosis in two infected dairy herds. Zentralbl Veterinarmed B 1994, 41:517-522.

73. Xenos G, Yiannati A, Dimarelli Z, Mtliangas P, Koutsoukou E: Evaluation of a live paratuberculosis vaccine in sheep and goats. In CEC Workshop Commission of the Economic Communities; Crete, Greece Edited by: PO 1988.

74. Aduriz Jj: Epidemiología, diagnóstico y control de la paratuberculosis ovina en la Comunidad Autónoma del País Vasco. University of Zaragoza, Spain; 1993.

75. Aduriz JJ, Juste RA, Sáez de Ocáriz C: An epidemiologic study of sheep paratuberculosis in the Basque Country of Spain: serology and productive data. In Proceedings of the 4th International Colloquium on Paratuberculosis; Rehoboth, MA, USA. Edited by: Chiodini RJ, Collins MT Bassey EOE. International Association for Paratuberculosis; 1995:19-26.

76. Cranwell MP: Control of Johne's disease in a flock of sheep by vaccination. Vet Rec 1993, 133:219-220.

77. Pérez V, García Marín JF, Bru R, Moreno B, JJ B: Resultados obtenidos en la vacunación de ovinos adultos frente a paratuberculosis. Med Vet 1995, 12:196-201.

78. Gwozdz JM, Thompson KG, Manktelow BW, Murray A, West DM: Vaccination against paratuberculosis of lambs already infected experimentally with Mycobacterium avium subspecies paratuberculosis. Aust Vet J 2000, 78:560-566.

79. Windsor PA, Eppleston J, Sergeant E: Monitoring the efficacy of Gudair ${ }^{\mathrm{TM}}$ OJD vaccine in Australia. Proc Aust Sheep Vet Soc 2003, 114-122.

80. Eppleston J, Reddacliff $L$, Windsor $P$, Whittington $R$, Jonbes $S$ : Field studies on vaccination for the control of OJD in Australia - and overview. Proc Aust Sheep Vet Soc 2004, 56-59.

81. Griffin JF, Hughes AD, Liggett S, Farquhar PA, Mackintosh CG, Bakker D: Efficacy of novel lipid-formulated whole bacterial cell vaccines against Mycobacterium avium subsp. paratuberculosis in sheep. Vaccine 2009, 27:911-918.

82. Hore DE, McQueen DS, McKinna DA: Infection of dairy cattle with Mycobacterium johnei in a partially vaccinated herd. Aust Vet $J$ 1971, 47:421-423.

83. Larsen $A B$, Merkal RS, Moon HW: Evaluation of a paratuberculosis vaccine given to calves before infection. Am J Vet Res 1974, 35:367-369.
84. Jorgensen JB: The effect of vaccination on the excretion of Mycobacterium paratuberculosis. In Proceedings of the International Colloquium on Paratuberculosis, I; NADC, USDA, Ames IA, USA. Edited by: Merkal RS. International Association for Paratuberculosis; 1983:249-254.

85. Argenté G: Efficiency of vaccination and other control measures estimated by fecal culturing in a regional program. In Proceedings of the 3rd International Colloquium on Paratuberculosis; Orlando, Florida, USA. Edited by: Chiodini RJ, Kreegel JM. International Association for Paratuberculosis: 1992:495-503.

86. Kormendy B: The effect of vaccination on the prevalence of paratuberculosis in large dairy herds. Vet Microbiol 1994, 41:117-125

87. Mohr P: Johne's can be managed. Johne's can be managed 2000, 16-17.

88. Kalis CH, Hesselink JW, Barkema HW, Collins MT: Use of long-term vaccination with a killed vaccine to prevent fecal shedding of Mycobacterium avium subsp paratuberculosis in dairy herds. Am J Vet Res 2001, 62:270-274

89. Klawonn W, Cussler K, Drager KG, Gyra H, Kohler H, Zimmer K, Hess RG: [The importance of allergic skin test with Johnin, antibody ELISA, cultural fecal test as well as vaccination for the sanitation of three chronically paratuberculosis-infected dairy herds in RhinelandPalatinate]. Dtsch Tierarztl Wochenschr 2002, 109:510-516.

90. Muñoz M, García Marín JF, García-Pariente C, Reyes LE, Verna A, Moreno O, Fuertes M, Doce J, Puentes E, Garrido J, Pérez V: Efficacy of a killed vaccine (SILIRUM) in calves challenged with MAP. In Proceedings of 8th International Colloquium on Paratuberculosis; Copenhagen, Denmark. Edited by: Manning EJB, Nielsen SS. International Association for Paratuberculosis; 2005:208-217.

91. Patton E, Konkle D, Fish R, Engrav J, Bohn J: Role of vaccination in the control of Johne's disease in 3 Wisconsin dairy herds. Book Role of vaccination in the control of Johne's disease in 3 Wisconsin dairy herds City: Wisconsin Department of Agriculture, Trade \& Consumer Protection, Division of Animal Health; 2006

92. Kathaperumal K, Park SU, McDonough S, Stehman S, Akey B, Huntley J, Wong S, Chang CF, Chang YF: Vaccination with recombinant Mycobacterium avium subsp. paratuberculosis proteins induces differential immune responses and protects calves against infection by oral challenge. Vaccine 2008, 26:1652-1663.

93. Sweeney RW, Whitlock RH, Bowersock TL, Cleary DL, Meinert TR, Habecker PL, Pruitt GW: Effect of subcutaneous administration of a killed Mycobacterium avium subsp paratuberculosis vaccine on colonization of tissues following oral exposure to the organism in calves. Am J Vet Res 2009, 70:493-497.

94. Brotherston JG, Gilmour NJL: Quantitative studies of Mycobacterium johnei in the tissues of sheep. I Routes of infection and assay of viable $M$. johnei. J Comp Pathol 1961, 71:286-299.

95. Nisbet DI, Gilmour NJ, Brotherston JG: Quantitative studies of Mycobacterium johnei in tissues of sheep. III. Intestinal histopathology. J Comp Pathol 1962, 72:80-91.

96. Juste RA, Garcia Marin JF, Peris B, Saez de Ocariz CS, Badiola JJ: Experimental infection of vaccinated and non-vaccinated lambs with Mycobacterium paratuberculosis. J Comp Pathol 1994, 110:185-194.

97. Dimareli-Malli Z, Sarris K, Papadopoulos O, N I, Xenos G, A M, Papadopoulos G: Evaluation of an inactivated whole cell experimental vaccine against paratuberculosis in sheep and goats. PTBC Newsletter 1997, 9:10-17.

98. Eppleston J, Reddacliff L, Windsor P, Links I, Whittington R: Preliminary observations on the prevalence of sheep shedding Mycobacterium avium subsp paratuberculosis after 3 years of a vaccination program for ovine Johne's disease. Aust Vet J 2005, 83:637-638.

99. Toribio JA, Sergeant ES: A comparison of methods to estimate the prevalence of ovine Johne's infection from pooled faecal samples. Aust Vet J 2007, 85:317-324.

100. Marly J, Thorel MF, Perrin GG, Pardon P, Guerrault PJ: Suivi de vaccination de chevrettes contre la paratuberculose: Consequences cliniques, serologiques et allergiques et epreuve virulente. In Proceedings of the International Colloquium on Paratuberculosis, Il; Laboratoire Central de Recherches Veterinaires. Maisons-Alfort. France. Edited by: Thorel MF, Merkal RS. International Association for Paratuberculosis; 1988:99-109.

101. Leslie P, Riemann HP, West G, Moe A: Vaccination field trial for Mycobacterium paratuberculosis (Johne's disease) in the caprine species. In Proceedings of the International Colloquium on Paratuberculosis, II; 
Laboratoire Central de Recherches Veterinaires. Maisons-Alfort, France. Edited by: Thorel MF, Merkal RS. International Association for Paratuberculosis; 1988:110-129.

102. Hines ME, Stiver S, Giri D, Whittington L, Watson C, Johnson J, Musgrove J, Pence M, Hurley D, Baldwin C, et al: Efficacy of spheroplastic and cell-wall competent vaccines for Mycobacterium avium subsp. paratuberculosis in experimentally-challenged baby goats. Vet Microbiol 2007, 120:261-283.

103. García-Pariente C, Pérez V, Geijo M, Moreno O, Muñoz M, Fuertes M, Puentes E, Doce J, Ferreras MC, Garcia Marin JF: The efficacy of a killed vaccine against paratuberculosis (SILIRUM ${ }^{\oplus}$ ) in cattle. A field study. In Proceedings of the 8th International Colloquium on Paratuberculosis; Copenhagen, Denmark. Edited by: Manning EJB, Nielsen SS. International Association for Paratuberculosis; 2005:52.

104. Sommerville EM, Wakelin RL, Hutton JB: Vaccination of lambs at 3 to 4 months of age protects against Johne's disease. PTBC Newsletter 1995, 7:25-29.

105. Reyes LE, González J, Benavides J: Nuevos adyuvantes en la vacunación frente a la paratuberculosis ovina. In XXVII Jornadas Cientificas y VI Jornadas Internacionales de la Sociedad Española de Ovinotecnia y Caprinotecnia, SEOC; Spain. Edited by: Peris Palau B, P. MP, LA M, GM A. SEOC; 2002:758-761.

106. Thonney ML SS, Smith MC: Control of Johne's disease in sheep by vaccination Preliminary Report. Control of Johne's disease in sheep by vaccination Preliminary Report Cornell University; 2005.

doi:10.1186/1476-8518-9-8

Cite this article as: Bastida and Juste: Paratuberculosis control: a review with a focus on vaccination. Journal of Immune Based Therapies and Vaccines 2011 9:8.

\section{Submit your next manuscript to BioMed Central and take full advantage of:}

- Convenient online submission

- Thorough peer review

- No space constraints or color figure charges

- Immediate publication on acceptance

- Inclusion in PubMed, CAS, Scopus and Google Scholar

- Research which is freely available for redistribution

Submit your manuscript at www.biomedcentral.com/submit
Biomed Central 